\title{
HUBUNGAN MUSCLE DYSMORPHIA DENGAN ASUPAN ENERGI DAN ZAT GIZI MAKRO PADA PRIA DEWASA USIA 19-29 TAHUN ANGGOTA FLOZOR SPORT CLUB SEMARANG
}

\author{
Maria Angela Dhiana, Fillah Fithra Dieny ${ }^{*}$ \\ Program Studi Ilmu Gizi Fakultas Kedokteran Universitas Diponegoro \\ Jl.Dr.Sutomo No.18, Semarang, Telp (024) 8453708, Email : gizifk@undip.ac.id
}

\begin{abstract}
Background: Men with negative body image trying to adding muscle with weight training. Excessive weight training can cause muscle dysmorphia (MD).Muscle Dysmorphiais one of the possible factors that may affect change in young adult men's dietary pattern such as excessive protein consumption and excessive non-protein diet restrain. This diet pattern change necessarily affect energy and protein intake

Objective:This study was aimed to analyze the correlation between MD with energy and protein intake on young adult men aged 19-29 y.o.

Methods: Thiscross-sectionalstudy was conducted on adult men aged 19-29 y.o. at FLOZOR Sport ClubSemarang with inclusion criteria exercised at least twice a week in FLOZOR SportCluband not being on special diet because of certain disease. The selection of 39 subjects was performed by consecutive sampling technique. Energy and protein intake data were obtained byfoodrecall24hcompared with RDA for Indonesian people, MD score data was collected by Drive for Muscularity Scale (DMS), Anthropometric data measurements included weight, height and body fat percentage, exercise frequency and duration, supplement consumption collected with questionnaire.Correlation between MD and energy, carbohydrate and fat intake were analyzed by Pearson correlation testandcorrelation between MD and protein intake were analyzed by Spearmancorrelation test.

Result: A total of 64,1\% (n=25) subjects had fitness body fat percentage. 51.3\% $(n=20)$ subjects exercised 4-5 times per week; $56.4 \%(n=22)$ subjects spent 90-120 minutes per day for exercising. As much as 33.3\% $(n=13)$ subjects took muscle mass enhancersupplements. All subjects $(n=39)$ experienced a severe deficit of energy and carbohydrate intake. Only $10.2 \%(n=4)$ subjects recorded with normal protein intake, even there were $10.2 \%(n=4)$ subjects categorized as excessive protein intake, all of them consumed muscle mass enhancersupplements. A total of $89,9 \%$ subjects experienced severe deficit of fat intake. A total of $46.2 \%(n=18)$ subjects diagnosed with MD. Correlation test showed no relationship between Muscle Dysmorphia with energy, carbohydrate and protein intake $(p=0,644$; $p=0,232 ; p=0,570)$. There were a significant correlation between Muscle Dysmorphia with fat intake $(r=-0,369$; $p=0,021)$
\end{abstract}

Conclusion: There were no significant correlation between Muscle Dysmorphiaeither with energy, carbohydrate or protein intake, but there was a significant correlation between Muscle Dysmorphia with fat intake

Keywords: Muscle Dysmorphia; energy intake; macronutrientintake; young adult men

\section{ABSTRAK}

Latar Belakang: Laki - laki dengan citra tubuh negatif berusaha untuk meningkatkan massa otot dengan latihan angkat beban. Latihan angkat beban yang berlebihan dapat menyebabkan muscle dysmorphia (MD). Muscle Dysmorphia merupakan salah satu faktor yang dapat mempengaruhi perubahan pola makan pada pria dewasa yaitu konsumsi protein yang berlebihan, membatasi asupan zat gizi non-protein. Perubahan pola makan ini tentu mempengaruhi asupan energi dan protein.

Tujuan: Penelitian ini bertujuan untuk mengetahui hubungan antara MD dengan asupan energi dan protein pada dewasa pria usia 19-29 tahun.

Metode: Studi cross-sectional pada anggota FLOZOR Sport Club Semarang usia 19-29 tahun dengan kriteria inklusi melakukan latihan rutin minimal dua kali seminggu dan tidak sedang menjalani diet khusus karena penyakit tertentu. Tiga puluh Sembilan subjek diambil dengan metode consecutive sampling. Data asupan energi dan protein diperoleh dari food recall 24h dibandingkan dengan AKG untuk warga Indonesia, data skor MD dengan angket Drive for Muscularity Scale (DMS), data antropometri dari pengukuran berat badan, tinggi badan dan persen lemak tubuh, data frekuensi dan durasi latihan serta konsumsi suplemen massa otot diperoleh dari kuesioner. Analisis data menggunakan analisis uji korelasi Pearson pada MD dengan asupan energy, karbohidrat dan lemak, dan uji korelasi Spearman pada MD dengan asupan protein.

Hasil: Sebanyak 64,1 \% (n=25) subjek memiliki kategori persen lemak tubuh kategori fitness. Sebesar 51,3\% (n=20) subjek berlatih 4-5 kali per minggu; 56,4\% (n=22) subjek berlatih 90-120 menit per hari. sebanyak 33,3\% (n=13) subjek mengkonsumsi suplemen penambah massa otot. Semua subjek $(n=39)$ mengalami defisit energi dan karbohidrat tingkat berat. Hanya 10,2 \% (n=4) subjek yang asupan proteinnya normal, bahkan terdapat 10,2\% (n=4) subjek yang termasuk kategori asupan protein berlebih, semuanya mengkonsumsi suplemen penambah massa otot. Subjek yang mengalami defisit asupan lemak tingkat berat sebesar 89,8\%. Sebanyak 46,2 \% (n=18) subjek

${ }^{*}$ Penulis Penanggungjawab 
terdiagnosis mengalami MD. Uji korelasi menunjukan tidak adanya hubungan antara MD dengan asupan energi, karbohidrat dan protein. $(p=0,644 ; p=0,232 ; p=0,570)$. Ada hubungan antara MD dengan asupan lemak $(r=-0,369$; $p=0,021$ )

Kesimpulan: Tidak ada hubungan antara Muscle Dysmorphia dengan asupan energi, karbohidrat dan protein. Ada hubungan antara Muscle Dysmorphia dengan asupan lemak

Kata Kunci: Muscle Dysmorphia; asupan energi; asupan zat gizi makro; laki-laki dewasa

\section{PENDAHULUAN}

Body image atau citra tubuh merupakan persepsi seseorang tentang bentuk tubuh dan ukuran tubuh. ${ }^{1}$ Pria dengan citra tubuh negatif berusaha untuk meningkatkan berat badannya dengan menambah massa otot. Hal ini disebabkan oleh pengaruh sosial budaya yang ada pada masyarakat dan juga paparan media massa yang menggambarkan tubuh ideal pria sebagai pria yang berotot, kencang dan atletis. ${ }^{2-4}$ Dalam mencapai gambaran tubuh idealnya, pria cenderung mengarah kepada peningkatan aktifitas fisik untuk membentuk otot dengan latihan angkat beban. Keinginan untuk memiliki tubuh yang berotot berbanding lurus dengan peningkatan latihan angkat beban. ${ }^{5}$ Latihan angkat beban yang berlebihan untuk mencapai gambaran tubuh ideal ini dapat menyebabkan kerugian terhadap kesehatan fisik dan mental seperti ketergantungan latihan, penyalahgunaan obat - obatan steroid dan muscle dysmorphia (MD).

Muscle Dysmorphia (MD) merupakan obsesi patologis seseorang tentang otot dan kerampingan. MD merupakan sub-kategori dari Body Dysmorphic Disorder (BDD). ${ }^{6}$ Muscle Dysmorphia ditandai dengan adanya kekhawatiran yang berlebih bahwa tubuh seseorang tidak cukup berotot atau terlalu kecil dan adanya keinginan secara kompulsif untuk menjaga jadwal latihan. ${ }^{7}$ Penelitian terdahulu menyatakan, meskipun jumlah pastinya tidak dapat diperkirakan, 100.000 atau lebih orang di dunia memenuhi kriteria diagnosis MD. ${ }^{8}$ Semakin banyak pria yang berlatih angkat beban untuk memperbesar otot, semakin banyak kasus MD ditemukan. Pria dengan MD terbukti memiliki citra tubuh yang lebih negatif, lebih tidak menyukai tubuh mereka dan sangat khawatir dengan berat badan, dan bentuk panggul, paha dan kaki mereka dibandingkan pria yang tidak MD. ${ }^{9}$

Muscle dysmorphia juga disebabkan oleh pengaruh media massa dan sosial budaya pada masyarakat luas, maupun pengaruh faktor psikologis dari dalam diri seseorang. ${ }^{6} \mathrm{MD}$ menyebabkan gangguan pada kehidupan sehari hari seseorang karena mereka menghabiskan waktu yang berlebihan untuk pergi ke pusat kebugaran dan mengabaikan kehidupan sosial mereka. Muscle Dysmorphia juga berefek negatif kepada kesehatan fisik, seperti penggunaan steroid dan perubahan perilaku makan.Muscle Dysmorphia merupakan salah satu faktor yang dimungkinkan dapat mempengaruhi perubahan pola makan pada pria dewasa. Penelitian menunjukkan bahwa $76 \%$ pria dewasa tidak ingin kehilangan bobot badannya. ${ }^{10}$ Disisi lain orang-orang yang melakukan pembentukan otot seringkali menunjukan adanya perubahan pola makan seperti konsumsi protein yang berlebihan, membatasi secara berlebihan asupan komponen makanan non-protein termasuk didalamnya karbohidrat atau lemak ${ }^{11}$ Perubahan pola makan ini tentu mempengaruhi tingkat kecukupan energi dan zat gizi makro, guna tetap menjaga asupan kualitas gizi tubuh. Faktor - faktor psikopatologi dari anorexia nervosa seperti evaluasi berlebihan terhadap pola makan terlihat juga pada MD, namun kearah sebaliknya. ${ }^{12}$ Ketidakpuasan otot dan penggunaan suplemen atau steroid sering mucul pada pria usia dewasa awal, hal ini dihubungkan dengan tekanan secara psikologis dan sebagai penanda gaya hidup. ${ }^{13}$

Studi yang mengulas tentang artikel artikel penelitian MD menyebutkan bahwa subjek penelitian pelaku latihan angkat beban di pusat kebugaran menerapkan suatu pola diet yang digunakan untuk menambah massa otot dan mengurangi lemak tubuh, namun diet yang ada tidak sepenuhnya dipatuhi. Terdapat bukti bahwa subjek - subjek tersebut mengatur sendiri pola diet mereka secara sembarangan, tanpa panduan dari ahli. ${ }^{14}$ Menurut studi, sebanyak $10 \%$ dari binaraga di Amerika Serikat menderita MD dan total pria yang menggunakan steroid melebihi dua juta jiwa. ${ }^{8}$ Belum ada laporan tentang prevalensi MD di Indonesia, namun diduga kasus MD juga terjadi di Indonesia.

FLOZOR Sport Club merupakan pusat kebugaran yang terletak di tengah kota Semarang yang telah banyak melahirkan atlet binaraga amatir. FLOZOR Sport Club menyediakan fasilitas angkat beban yang relatif lengkap dengan biaya keanggotaan yang terjangkau, sehingga banyak masyarakat kota Semarang yang memilih untuk berlatih disana.Berdasarkan paparan diatas, peneliti tertarik untuk menganalisis lebih lanjut mengenai hubungan antara muscle dysmorphia dengan asupan 
energi dan zat gizi makro pada pelaku fitness di klub kebugaran.

\section{METODE PENELITIAN}

Penelitian ini merupakan penelitian observasional dengan rancangan cross-sectoinal dan termasuk dalam ruang lingkup keilmuan gizi masyarakat.Pengambilan data dilakukan pada bulan Agustus 2014.Penelitian ini dilaksanakan di FLOZOR Sport Club Semarang dengan anggota Sport Club sebagai subjek penelitian.

Subjek penelitian diambil dengan cara consecutive sampling dimana subjek penelitian yang datang dan memenuhi kriteria dimasukkan dalam penelitian hingga jumlah subjek yang diperlukan terpenuhi. ${ }^{15}$ Kriteria pemilihan subjek penelitian yaitu pria usia 19-29 tahun anggota FLOZOR Sport Club yang melakukan latihan rutin di FLOZOR SportClub minimal dua kali seminggu, tidak sedang menjalani diet khusus karena penyakit tertentu, misalnya diet rendah protein pada penyakit ginjal atau diet rendah karbohidrat pada penyakit DM, dan bersedia menandatangani surat persetujuan informed consent.Terdapat 42 subjek yang berpartisipasi pada penelitian ini, namun 3 subjek drop out karena tidak memenuhi kriteria inklusi, yaitu berlatih angkat beban minimal dua kali dalam seminggu. Sehingga didapat 39 subjek penelitian dengan derajat kemaknaan sebesar 0,05.

Variabel terikat pada penelitian ini adalah asupan energi dan asupan zat gizi makro(Karbohidrat, Lemak, Protein) yang diperoleh dengan metode food recall 3 x 24 jam yang diperoleh dalam ukuran rumah tangga kemudian dikonversikan dalam gram menggunakan software nutrisurvey, dan dihitung rata - rata konsumsinya per hari, kemudiandikomparasikan dengan kebutuhan gizi subjek yang didapat dari Angka Kecukupan Gizi (AKG) dikalikan $100 \%$ sehingga didapat persentase tingkat kecukupan energi dan zat gizi makro. Tingkat asupan energi dan zat gizi makro dibagi menjadi limakategori, yaitu defisit berat $(<70 \%$ AKG individu), defisit sedang (70 - 79,9\% AKG individu), defisit ringan (80 - 89,9 \% AKG), normal / cukup (90 - 119,9\% AKG), lebih ( $\geq 120 \%$ AKG individu). ${ }^{16}$

Variabel bebas dalam penelitian ini adalah MD yang diukur menggunakan angket Drive for Muscularity (DMS) yang berisi 15 pernyataan mengenai penilaian terhadap otot tubuh diukur dengan rentang nilai 1-4 (1 untuk tidak pernah, 2 untuk kadang - kadang, 3 untuk sering dan 4 untuk selalu). (skor $\alpha$-Cronbach $=0,85-0,91) .{ }^{17}$ Hasil ukur diperoleh melalui skala model Likert dengan cut off point berdasarkan nilai rata - rata skor-T, yaitu MD ( $\geq$ mean skor-T) dan Non-MD ( $<$ mean skor-T). ${ }^{18}$ Meskipun banyak pengukuran yang digunakan untuk mengetahui kejadian MD, seperti Muscle Dysmorphia Inventory (MDI), DMS dipilih karena dapat mengukur secara spesifik variabel variabel dari MD. ${ }^{4}$

Data yang dikumpulkan berupa data kuantitatif karakteristik subjek meliputi data umur, antropometri, konsumsi suplemen penambah massa otot, frekuensi dan durasi latihan. Data kuantitatif yang dikumpulkan melalui pengukuran adalah data berat badan yang diperoleh melalui penimbangan dengan timbangan digital yang memiliki ketelitian $0,1 \mathrm{~kg}$, tinggi badan yang diperoleh melalui pengukuran dengan microtoisedengan ketelitian 0,1 $\mathrm{cm}$ dan persen lemak tubuh yang diperoleh melalui pengukuran dengan Bioelectrical Impedance Analyzer (BIA). Data konsumsi suplemen penambah massa otot, frekuensi dan durasi latihan diperoleh melalui kuesioner dan wawancara. Pengukuran berat badan dan tinggi badan digunakan untuk mengetahui status gizi subjek dengan menghitung indeks massa tubuh (IMT). IMT dikategorikan menjadi: $<18,5 \mathrm{~kg} / \mathrm{m}^{2}$ termasuk kurus, $18,5-23,9 \mathrm{~kg} / \mathrm{m}^{2}$ termasuk normal, $24,0-$ $26,9 \mathrm{~kg} / \mathrm{m}^{2}$ termasuk overweight dan $\geq 27 \mathrm{~kg} / \mathrm{m}^{2}$ termasuk obese. ${ }^{19}$ Persen lemak tubuh dikategorikan menjadi $2-5,9 \%$ termasuk kategori lemak esensial tubuh,6 - 13,9 \% termasuk atletik, $14-17,9 \%$ termasuk fitness, $18-24,9 \%$ termasukacceptable, dan $\geq 25 \%$ termasuk overweight atau obese. ${ }^{20}$

Analisis univariat dilakukan untuk mendeskripsikan data karakteristik subjek dan setiap variabel penelitian meliputi nilai maksimum dan minimum, nilai rata - rata, dan standar deviasi dengan tabel distribusi frekuensi pada usia subjek, IMT, persen lemak tubuh, status gizi, konsumsi suplemen penambah massa otot, frekuensi dan durasi latihan, asupan energi dan protein, tingkat kecukupan energi dan tingkat kecukupan protein serta skor MD. Variabel skor MD dan asupan energi dan zat gizi makro diuji kenormalannya dengan menggunakan uji kenormalan Shapiro-Wilk. ${ }^{21}$ Variabel skor MD dan asupan energi, karbohidrat dan lemakdiuji menggunakan uji korelasi Pearson product moment. Variabel skor MD dengan asupan proteindiuji menggunakan uji korelasi Rank Spearman. 


\section{HASILPENELITIAN \\ Karakteristik Subjek}

Tabel 1. Gambaran Umum Subjek

\begin{tabular}{llll}
\hline Variabel & Minimum & Maksimum & Rerata \pm SD \\
\hline Usia (tahun) & 19 & 29 & $24 \pm 2,9$ \\
Persen Lemak Tubuh (\%) & 9,6 & 23,9 & $16,5 \pm 3,5$ \\
BB $(\mathrm{kg})$ & 48,0 & 96,0 & $65,1 \pm 10,7$ \\
TB $(\mathrm{cm})$ & 162,0 & 184,0 & $171,0 \pm 5,0$ \\
IMT $\left(\mathrm{kg} / \mathrm{m}^{2}\right)$ & 17,2 & 31,7 & $22,2 \pm 2,9$ \\
Asupan Energi (kkal) & 557,0 & 1822,4 & $1091,4 \pm 290,8$ \\
Tingkat Kecukupan Energi (\%) & 20,4 & 66,9 & $40,1 \pm 10,7$ \\
Asupan Karbohidrat (gram) & 35,4 & 259,0 & $125,7 \pm 41,2$ \\
Tingkat Kecukupan Karbohidrat (\%) & 9,4 & 69,1 & $33,5 \pm 11,0$ \\
Asupan Lemak (gram) & 15,6 & 77,7 & $43,9 \pm 14,5$ \\
Tingkat Kecukupan Lemak (\%) & 17,1 & 85,3 & $48,2 \pm 15,9$ \\
Asupan Protein (gram) & 20,9 & 97,1 & $47,4 \pm 17,3$ \\
Tingkat Kecukupan Protein $(\%)$ & 33,7 & 156,5 & $76,5 \pm 27,9$ \\
MD (Skor-T DMS) & 26,7 & 68,9 & $50,0 \pm 10,0$ \\
\hline
\end{tabular}

Subjek penelitian yang berada pada kelompok usia 19 - 24 tahun sebanyak 22 subjek (56,4\%) dan kelompok usia 25-29 tahun sebanyak 17 subjek dengan rerata umur 24 tahun $\pm 2,9$, status gizi sebagian besar subjek normal $(74,4 \%)$ dengan rerata IMT $22,2 \mathrm{~kg} / \mathrm{m}^{2} \pm 2,9$ serta persen lemak tubuh termasuk dalam kategori fitness $(64,1 \%)$ dengan rerata $16,5 \% \pm 3,5$. Rerata asupan energi subjek 1091,4kkal $\pm 290,8$; asupan karbohidrat 125,7 gram $\pm 41,2$; asupan lemak 43,9 gram $\pm 14,5$ dan rerata asupan protein 47,4 gram \pm 17,3.Gambaran umum dari subjek penelitian dapat dilihat di tabel 1.

Sebanyak 51,3\% subjek berlatih angkat beban $4-5$ kali dalam seminggu; $15,4 \%$ berlatih angkat beban 6 kali seminggu. Lebih dari separuh subjek $(56,4 \%)$ memilih durasi latihan $90-120$ menit per hari dan $10,3 \%$ subjek berlatih lebih dari 120 menit per hari. Hanya sebagian subjek (33,3 $\%$ yang mengkonsumsi suplemen penambah massa otot. Subjek penelitian yang terdiagnosis MD berdasarkan skor-T DMS sebesar 46,2 \% $(\mathrm{n}=18)$.Asupan energi dan asupan karbohidrat semua subjek termasuk dalam kategori defisit tingkat berat, $89,8 \%$ subjek mengalami defisit asupan lemak tingkat berat dan 51,3\% subjek mengalami defisit asupan protein tingkat berat. Pada subjek dengan kategori asupan protein lebih $(n=4)$, semuanya mengkonsumsi suplemen penambah massa otot.Distribusi frekuensi menurut karakteristik subjek penelitian dapat dilihat pada tabel 2.

Tabel 2. Distribusi Frekuensi Karakteristik Subjek

\begin{tabular}{lrc}
\hline Variabel & $\begin{array}{c}\text { Frekuensi } \\
(\mathrm{n})\end{array}$ & $\begin{array}{c}\text { Persentase } \\
(\%)\end{array}$ \\
\hline Kelompok Umur & 22 & 56,4 \\
19-24 tahun & 17 & 43,6 \\
25-29 tahun & & \\
\hline Status Gizi & 2 & 5,1 \\
$\quad$ kurus & 29 & 74,4 \\
normal & 5 & 12,8 \\
overweight & 3 & 7,7 \\
obese & & 15,4 \\
\hline Persen Lemak Tubuh & 6 & 64,1 \\
Atletik & 25 & 20,5 \\
Fitness & 8 & 33,3 \\
Acceptable & & 51,3 \\
\hline Frekuensi Latihan & 13 & 15,4 \\
2-3 kali & 20 & 33,3 \\
4-5 kali & 6 & \\
6 kali & &
\end{tabular}




\begin{tabular}{lrc}
$90-120$ menit & 22 & 56,4 \\
$>120$ menit & 4 & 10,3 \\
\hline Konsumsi Suplemen & 13 & 33,3 \\
ya & 26 & 66,7 \\
tidak & 18 & \\
\hline Muscle Dysmorphia & 21 & 46,2 \\
MD & & 53,8 \\
NonMD & 39 & \\
\hline Asupan Energi & & \\
Defisit berat & 39 & 100,0 \\
\hline Asupan Karbohidrat & & \\
Defisit berat & 35 & 89,0 \\
\hline Asupan Lemak & 2 & 5,1 \\
Defisit berat & 2 & 5,1 \\
Defisit sedang & & \\
Defisit ringan & 20 & 51,3 \\
\hline Asupan Protein & 4 & 10,2 \\
Defisit berat & 7 & 18,1 \\
Defisit sedang & 4 & 10,2 \\
Defisit ringan & 4 & 10,2 \\
Normal / Cukup & 39 & 100,0 \\
Lebih & & \\
\hline Total &
\end{tabular}

\section{Hubungan antara MD dengan Asupan Energi dan Protein}

Tabel 3. Distribusi Frekuensi Asupan Zat Gizi Makro menurut Kejadian MD

\begin{tabular}{lcccccr}
\hline \multirow{2}{*}{ Asupan Zat Gizi } & \multicolumn{2}{c}{ MD } & \multicolumn{2}{c}{ NonMD } & \multicolumn{2}{c}{ Total } \\
\cline { 2 - 7 } & $\mathrm{n}$ & $\%$ & $\mathrm{n}$ & $\%$ & $\mathrm{n}$ & $\%$ \\
\hline Asupan Energi & 18 & 46,2 & 21 & 53,8 & 39 & 100,0 \\
$\quad$ Defisit berat & 11 & 28,2 & 9 & 23,1 & 20 & 51,3 \\
\hline Asupan Protein & 2 & 5,1 & 2 & 5,1 & 4 & 10,2 \\
$\quad$ Defisit berat & 2 & 5,1 & 5 & 12,8 & 7 & 18,1 \\
$\quad$ Defisit sedang & 1 & 2,6 & 3 & 7,7 & 4 & 10,2 \\
Defisit ringan & 2 & 5,1 & 2 & 5,1 & 4 & 10,2 \\
Normal / Cukup & & & & & & \\
Lebih & 18 & 46,2 & 21 & 53,8 & 39 & 100,0 \\
\hline Asupan Karbohidrat & & & & & & \\
Defisit berat & 18 & 46,2 & 17 & 43,6 & 35 & 89,8 \\
\hline Asupan Lemak & 0 & - & 2 & 5,1 & 2 & 5,1 \\
$\quad$ Defisit berat & 0 & - & 2 & 5,1 & 2 & 5,1 \\
Defisit sedang & 18 & 46,2 & 21 & 53,8 & 39 & 100,0 \\
$\quad$ Defisit ringan & & & & & & \\
\hline Total & & & & & & \\
\hline
\end{tabular}

Kategori asupan protein defisit berat paling banyak terjadi pada subjek MD (28,2\%). Kategori asupan lemak desifit berat pada subjek MD dan NonMD hampir sama jumlahnya $(n=18$ dan $n=17)$.
Distribusi frekuensi asupan energi dan zat gizi makro menurut kejadian MD dapat dilihat di tabel 3 .

Tabel 4. Hubungan antara Muscle Dysmorphia dengan Asupan Energi dan Asupan Zat Gizi Makro

\begin{tabular}{lcc}
\hline Variabel & $\mathrm{r}$ & $\mathrm{p}$ \\
\hline Asupan Energi & $-0,076$ & 0,644 \\
Asupan Karbohidrat & 0,196 & 0,232 \\
Asupan Protein & $-0,094$ & 0.570 \\
Asupan Lemak & $-0,369$ & $0.021^{*}$ \\
\hline
\end{tabular}

$$
* \mathrm{p}<0,05
$$


Hasil uji korelasi antara MD dengan asupan energi menunjukkan tidak adanya hubungan dengan nilai $r=-0,076$ dan $\mathrm{p}=0,644(\mathrm{p}>0,05)$ yang memiliki arah korelasi negatif. Hasil uji korelasi antara MD dengan asupan karbohidrat menunjukkan tidak ada hubungan dengan nilai $\mathrm{r}=0,196$ dan $\mathrm{p}=0,232$ $(\mathrm{p}>0,05)$. Hasil uji korelasi antara MD dengan asupan protein menunjukkan tidak adanya hubungan dengan nilai $\mathrm{r}=-0,094$ dan $\mathrm{p}=0,570$ $(p>0,05)$. Hasil uji korelasi antara MD dengan asupan lemak menunjukkan adanya hubungan dengan nilai $r=-0,369$ dan $p=0,021(p<0,05)$ yang memiliki arah korelasi negatif. Artinya semakin tinggi skor-T DMS yang menunjukkan adanya kejadian MD sejalan dengan semakin menurunnya asupan lemak.

\section{PEMBAHASAN \\ Usia Subjek}

Subjek penelitian sebagian besar berada pada kelompok usia 19-24 tahun dengan rerata usia $24 \pm 2,9$ tahun. Kelompok umur ini termasuk kedalam usia dewasa awal dimana individu mulai masa berlomba - lomba meningkatkan harga diri demi menyesuaikan diri dengan nilai masyarakat dan kelompok sekitarnya. Peningkatan harga diri (self-esteem) salah satunya dengan memperbaiki citra tubuh dengan melakukan latihan angkat beban. Hal ini sesuai dengan penelitian yang menyatakan bahwa ada hubungan positif antara citra tubuh dengan harga diri pada remaja pria yang mengikuti fitness. ${ }^{22}$ Keinginan untuk meningkatkan massa otot berhubungan positif dengan bertambahnya usia, hal ini diperkuat oleh penelitian yang menunjukkan bahwa pria mulai usia 18 tahun menunjukkan keinginan yang besar untuk meningkatkan massa otot, dan keinginan semakin bertambah seiring bertambahnya usia. ${ }^{23}$ Penelitian terdahulu menyatakan bahwa usia terjadinya $\mathrm{MD}$, menurut laporan retrospektif, adalah 19,4 tahun $\pm 0,36 .{ }^{24}$

\section{Persentase Lemak Tubuh dan Status Gizi}

Priayang memiliki citra tubuh negatif dihubungkan dengan dua faktor: keinginan meningkatkan massa otot dan mengurangi lemak tubuh..${ }^{9} 25$ Persentase lemak tubuh sering dihubungkan dengan muskularitas. Persen lemak tubuh yang rendah memungkinkan garis - garis otot lebih terlihat. ${ }^{2}$ Pada penelitian ini, persen lemak tubuh sebagian besar subjek termasuk dalam kategori fitness $(64,1 \%)$, terdapat subjek yang persentase lemak tubuhnya termasuk dalam kategori atletik (15.4\%) dan kategori acceptable (20,5\%). Subjek pada penelitian ini cenderung berusaha untuk mencapai kategori lemak tubuh atletik (6 -
13,9 \%) dengan menambah massa otot, dibuktikan dengan semua subjek dengan MD menjawab "sering" dan "selalu" pada pernyataan pada angket DMS butir kedua "saya latihan angkat beban untuk membentuk otot". Hasil penelitian ini tidak sesuai dengan studi yang meneliti faktor - fator terkait muskularitas yang menyatakan bahwa tidak ada hubungan antara IMT, persen lemak tubuh, massa tubuh bebas lemak dengan keinginan meningkatkan muskularitas. ${ }^{26}$ Status Gizi pada subjek sebagian besar normal $(74,4 \%)$ dengan rerata IMT 22,2 $\mathrm{kg} / \mathrm{m}^{2} \pm 2,9$. Ketidakpuasan tubuh pada pria mempunyai korelasi negatif dengan status gizi menurut IMT. ${ }^{27}$ Semakin tinggi nilai IMT, semakin pria tidak puas terhadap tubuh mereka.menganggap diri mereka kurang berotot dan berusaha untuk melakukan latihan angkat beban dan cara -cara lain untuk memperoleh massa otot mereka. ${ }^{28}$

\section{Frekuensi dan Durasi Latihan}

Frekuensi dan durasi latihan sering dikaitkan dengan tingkat ketidakpuasan otot pada binaraga.Semakin tinggi ketidakpuasan otot maka semakin panjang frekuensi dan durasi yang dihabiskan untuk latihan. Teori tersebut sesuai dengan penelitian yang menyatakan binaraga yang mengkonsumsi suplemen dan berlatih lebih dari 6 jam per minggu menunjukan skor MDI (Muscle Dysmorphia Inventory) yang lebih tinggi. ${ }^{29}$ Hasil penelitian ini menyebutkan sebanyak $51,3 \%$ subjek berlatih angkat beban $4-5$ kali dalam seminggu; $15,4 \%$ berlatih angkat beban 6 kali seminggu. Sebanyak 56,4\% subjek memilih durasi latihan 90 -120 menit per hari dan 10,3\% subjek berlatih lebih dari 120 menit per hari. Pada subjek MD, ditemukan dua subjek yang berlatih enam kali dalam seminggu, dan dua subjek yang berlatih dengan durasi lebih dari 120 menit per hari.WHO merekomendasikan dewasa awal setidaknya harus melakukan aktivitas fisik intensitas berat 75 - 150 menit per minggu, dan aktivitas yang berhubungan dengan massa otot harus dibarengi dengan fase "istirahat" untuk otot paling sedikit dua hari. ${ }^{30}$ Aktivitas fisik merupakan hal yang penting dalam mempertahankan kesehatan tubuh, tetapi tetap harus diperhatikan bahwa terlalu banyak melakukan aktivitas fisik dapat membahayakan. Masih banyak individu yang meski sudah mengetahui bahaya dari aktivitas berlebih, mereka masih melakukan aktivitas fisik diatas tingkat rekomendasi WHO. Hal ini dimungkinkan berhubungan dengan tekanan untuk memiliki tubuh ideal yang dapat diterima masyarakat. ${ }^{4}$

Subjekdengan MD pada penelitian ini paling banyakmenjawab "sering" dan "selalu" untuk penyataan "saya merasa bersalah apabila saya 
melewatkan jadwal latihan angkat beban saya" dan pernyataan "orang lain beranggapan saya terlalu sering latihan angkat beban" pada angket DMS namun mereka beranggapan bahwa jadwal latihan mereka tidak mengganggu aspek lain di kehidupan mereka $(n=30)$. Hal ini dimungkinkan adanya ketergantungan latihan pada subjek MD dilihat dari karakteristik spesifik dari ketergantungan latihan, yaitu kurangnya kontrol untuk mengurangi tingkat aktivitas fisik yang dilakukan, berlatih angkat beban secara terus menerus, dan mengurangi segala bentuk aktivitas lain. ${ }^{4}$ Perlu dilakukan penelitian lebih dalam apakah subjek benar - benar mengalami ketergantungan latihan.

\section{Konsumsi Suplemen Penambah Massa Otot}

Pada penelitian ini, sebesar 33,3\% subjek mengkonsumsi suplemen penambah massa otot. Suplemen yang paling sering dikonsumsi adalah suplemen dengan merk dagang Carnivor: Beef Protein Isolate yang mengandung 23 gram protein per takaran sajinya (1 scoop $=35$ gram). Pria, baik dewasa maupun remaja, menggunakan suplemen untuk menambah massa otot, mengurangi berat badan dan meningkatkan penampilan otot mereka. ${ }^{13,25,31}$ Penelitian menemukan bahwa remaja pria yang mengalami keterlambatan kedewasaan fisiologis lebih sering mengkonsumsi suplemen penambah massa otot dibandingkan remaja yang tidak mengalami keterlambatan kedewasaan fisiologis. ${ }^{28}$ Terdapat korelasi negatif yang kuat antara ketidakpuasan terhadap otot dengan konsumsi suplemen penambah massa otot secara rutin. ${ }^{13,29,32}$ Semakin tinggi ketidakpuasan terhadap massa otot, semakin banyak kejadian konsumsi suplemen ditemukan. Meskipun penjualan dan penggunaan suplemen penambah massa otot adalah legal, namun konsumsi suplemen secara terus menerus dapat menjadi "gerbang" bagi penggunaan steroid. ${ }^{23}$ Pada penelitian ini, ditemukan 6 subjek yang menjawab "jarang" dan 1 subjek yang menjawab "sering" pada butir "saya berpikir untuk menggunakan steroid" pada angket DMS, dimana sisanya menjawab "tidak pernah". Penggunaan steroid berhubungan dengan berbagai resiko penyakit kardiovaskuler, tumor hati, infertilitas, dan mengarah kepada masalah fisiologis organ dan sistem tubuh. ${ }^{31}$

\section{Muscle Dysmorphia}

Muscle Dysmorphia ditandai dengan adanya kekhawatiran yang berlebih bahwa tubuh seseorang tidak cukup berotot atau terlalu kecil dan adanya keinginan secara kompulsif untuk menjaga jadwal latihan. ${ }^{7}$ Penelitian terdahulu menyatakan, meskipun jumlah pastinya tidak dapat diperkirakan,
100.000 atau lebih orang di dunia memenuhi kriteria diagnosis MD. ${ }^{8}$ Semakin banyak pria yang berlatih angkat beban untuk memperbesar otot, semakin banyak kasus MD ditemukan. Hasil penelitian ini menunjukan terdapat 18 subjek dengan MD dari 39 subjek yang ada, dilihat dari skor-T DMS subjek. Hal ini sejalan dengan penelitian yang menyimpulkan dari lima juta keanggotaan pada pusat kebugaran di Amerika Serikat, dimungkinkan sedikitnya $5 \%$ atau 250.000 orang mengalami MD. ${ }^{4}$

\section{Asupan Energi}

Energi merupakan hasil dari metabolisme karbohidrat, lemak dan protein serta berfungsi sebagai zat tenaga untuk metabolisme, pertumbuhan, pengaturan suhu tubuh dan aktivitas fisik. Asupan energi merupakan jumlah rerata energi dari makanan dan minuman yang dikonsumsi individu. ${ }^{33}$ Asupan energi semua subjek penelitian termasuk kategori defisit berat dengan rerata asupan $1091,4 \mathrm{kkal} \pm 290,8$ dan rerata kecukupan energi subjek berkisar antara 40,1\% \pm 10,7 AKE (Angka Kecukupan Energi). Angka kecukupan energi yang dianjurkan untuk pria dewasa kelompok usia 19-29 tahun adalah $2725 \mathrm{kkal}$ per orang per hari. ${ }^{34}$ Pria lebih memilih untuk membatasi asupan energi dengan pola konsumsi rendah lemak, rendah karbohidrat dan tinggi protein daripada menghitung dan mengurangi jumlah kalori yang masuk. ${ }^{2,35}$ Data food recall menunjukkan sebagian besar subjek memiliki pola makan yang hampir sama, yaitu pembatasan asupan makan di hari selanjutnya jika pada hari sebelumnya asupan energi subjek berlebih.Pembatasan asupan ini dapat beresiko mengakibatkan defisiensi zat gizi makro dan mikro. ${ }^{35}$

\section{Asupan Karbohidrat}

Subjek penelitian semuanya mengalami defisit asupan karbohidrat tingkat berat dengan rerata asupan karbohidrat sebesar 125,7 gram \pm 41,2 dan rerata kecukupan karbohidrat subjek berkisar antara 33,5\% $\pm 11,0$. Angka kecukupan karbohidrat untuk pria dewasa usia 19-29 tahun adalah 375 gram per orang per hari. ${ }^{34}$ Kekurangan asupan karbohidrat, terutama serat, dapat meningkatkan resiko terjadinya penyakit kronis pada individu. ${ }^{39}$ Data asupan dari food recall 3 x 24 jam menunjukkan subjek pada penelitian ini melakukan pembatasan konsumsi nasi sebagai sumber karbohidrat. Subjek lebih sering mengkonsumsi buah - buahan dansusu, baik susu sapi maupun susu suplemen protein, sebagai sumber karbohidrat. Bahkan ada salah satu subjek yang melakukan diet paleo $^{36}$, yang membatasi konsumsi karbohidrat secara berlebihan.Keinginan untuk meningkatkan massa 
otot dapat dikaitkan dengan karakteristik gangguan makan yang ditandai dengan berbagai macam aturan perilaku makan, salah satunya dengan mencairkan makanan atau pemilihan makanan cair untuk mempermudah konsumsi energi. ${ }^{11,12}$

\section{Asupan Protein}

Subjek yang memiliki kategori asupan protein defisit berat sebesar $51,3 \%$. Rerata kecukupan protein subjek berkisar antara 76,5\%土 27,9 dengan rerata asupan protein subjek sebesar 47,5 gram $\pm 17,3$ jika dibandingkan dengan angka kecukupan protein pada pria dewasa usia 19-29 tahun sebesar 62 gram per orang per hari. ${ }^{34}$ Asupan protein sangat penting pada masa tumbuh kembang anak, namun penting juga untuk masa dewasa. Individu yang asupan proteinnya rendah mengalami keseimbangan negatif nitrogen, yaitu lebih banyak nitrogen yang dikeluarkan dari tubuh daripada yang diserap tubuh.Pada tahap ini, jaringan tubuh, seperti otot dan hemoglobin dapat kehilangan daya tahan dan kekuatannya. Kecukupan protein juga mempunyai peranan penting pada perkembangan tulang, yaitu mempengaruhi peak bone mass. Asupan protein yang rendah dapat merugikan bagi perolehan massa tulang selama pertumbuhan dan cadanganselama dewasa. Defisit protein pada dewasa lebih mungkin disembuhkan dengan pemberian zat gizi yang adekuat. ${ }^{35}$

Semua subjek $(n=4)$ dengan kategori asupan protein lebih mengkonsumsi suplemen penambah massa otot. Hal ini sesuaiteori yang mengatakan bahwa pelaku latihan angkat beban mengkonsumsi 1,0 - 3,5 gram protein per kilogram berat badannya per hari, dan sebagian besar didapat dari suplemen. ${ }^{37}$ Hasilpenelitian sejalan dengan penelitian terdahulu yang menyatakan peningkatan muskularitas dipengaruhi oleh konsumsi suplemen, ketergantungan latihan dan rendahnya harga diri, dan pria cenderung menggunakan berbagai cara secara bersamaan untuk meningkatkan massa otot. ${ }^{26}$ Mengkonsumsi protein secara berlebihan tidak dianjurkan dan sebaiknya dihindari. Diet tinggi protein dapat menimbulkan efek diuretik dan berpotensi mengakibatkan dehidrasi. ${ }^{37}$

\section{Asupan Lemak}

Sebanyak 89,8 \% subjek mengalami defisit asupan lemak tingkat berat, masing - masing 5,1\% sisanya mengalami defisit tingkat sedang dan ringan. Rerata asupan lemak subjek adalah 43,9 gram $\pm 14,5$ dengan tingkat kecukupan sebesar 48,2 $\% \pm 15,9$ dari angka kecukupan lemak menurut Permenkes No.75 tahun 2013 yaitu 91 gram per orang per hari untuk pria dewasa kelompok umur 19-29 tahun. ${ }^{34}$ Data asupan subjek dari food recall menunjukkan makanan yang dikonsumsi subjek sebagian besar diolah dengan cara direbus atau ditumis yang menggunakan sedikit minyak.

Defisit asupan lemak pada subjek diduga akibat adanya pembatasan asupan yang dilakukan subjek.Pembatasan asupan lemak sejatinya membawa dampak positif bagi tubuh. Pembatasan konsumsi sumber lemak jenuh, lemak trans, dan kolesterol serta lemak total dapat membantu mengatasi masalah penyakit jantung koroner (PJK), beberapa tipe kanker dan obesitas. ${ }^{38}$ Subjek penelitian ini membatasi asupan makanan termasuk lemak tanpa memperhatikan lemak apa saja yang harus dibatasi maupun yang baik untuk dikonsumsi.Hal ini diduga karena pengetahuan gizi mereka yang rendah, atau mereka mendapatkan informasi pengetahuan yang salah dari media sosial, instruktur fitness maupun teman sesama pelaku fitness. Pembatasan asupan lemak juga diduga karena subjek penelitian berusaha untuk mengurangi lemak tubuh untuk mencapai kategori persentase lemak tubuh atletik, sehingga mereka takut mengkonsumsi makanan sumber lemak karena akan dianggap akan mempengaruhi persentase lemak tubuh mereka.

\section{Hubungan antara Muscle Dysmorphia dengan Asupan Energi dan Zat Gizi Makro}

Pria yang melakukan latihan angkat beban diindikasikan melakukan diet yang tidak sehat ${ }^{26}$ yang dapat mempengaruhi asupan energi namun dari analisis bivariat tidak terdapat korelasi yang signifikan antara MD dengan asupan energi, karbohidrat dan protein pada penelitian ini. Hasil penelitian ini bertentangan dengan teori yang menyatakan karakteristik utama pola makan penderita MD adalah konsumsi diet tinggi protein dan rendah lemak dengan konsumsi suplemen untuk menambah massa otot dan menurunkan massa lemak tubuh. ${ }^{24} \mathrm{Hasil}$ analisis bivariat menunjukkan korelasi yang signifikan $(p=0,021)$ antara MD dengan asupan lemak $(r=-0,369)$ dengan arah korelasi negatif. Artinya semakin tinggi skor-T DMS yang menunjukkan adanya kejadian MD sejalan dengan semakin menurunnya asupan lemak.

Sebagian besar subjek pada penelitian ini tidak hanya mengalami defisit berat energi namun juga defisitzat gizi makro lainnya.Hal ini disebabkan oleh pola makan subjek yang kurang tepat. Data food recall menunjukan sebagian besar subjek memiliki pola makan yang hampir sama, yaitu pembatasan asupan makan di hari selanjutnya jika pada hari sebelumnya asupan energi subjek berlebih.Sebagian subjek juga menganut diet populer tertentu yang membatasi asupan zat gizi 
makro tertentu.Pola makan yang kurang tepat ini diduga karena tingkat pengetahuan subjek tentang gizi seimbang dan makanan sumber zat gizi makro rendah.Penelitian lebih lanjut perlu dilakukan untuk melihat tingkat pengetahuan subjek.

Pria yang melakukan latihan angkat lebih memilih menggunakan suplemen untuk mempercepat peningkatan massa otot, daripada melakukan perubahan perilaku makan seperti yang dilakukan atlet binaraga professional. ${ }^{26}$ Penelitian terdahulu yang membandingkan kejadian MD pada binaraga dan pelaku fitness menyimpulkan bahwa latihan angkat beban pada atlet binaraga dianggap lebih beresiko kearah MD daripada latihan angkat beban biasa pada pelaku fitness. ${ }^{29} \mathrm{Hal}$ ini tidak lepas dari adanya pengaruh motivasi diri dari dalam diri atlet binaraga untuk meningkatkan performa agar dapat memenangkan kompetisi dengan melakukan perubahan perilaku makan. Motivasi diri pada pelaku fitness amatir untuk sekedar meningkatkan harga diri, tidak terlalu kuat untuk merubah perilaku makan untuk mempercepat peningkatan massa otot seperti pada atlet binaraga professional.Hal ini dapat menjadi dasar mengapa tidak ada perbedaan signifikan dari jumlah asupan energi dan zat gizi makro pada subjek MD dan NonMD.

Penelitian tentang muskularitas dan gangguan makan pada pria yang menyimpulkan ketidakpuasan pada lemak tubuh, bukan pada muskularitas tubuh sebagai faktor peningkat perilaku pembatasan makanan dan kekhawatiran terhadap berat badan ${ }^{40}$ dimungkinkan dapat menjadi dasar mengapa hipotesis dari penelitian ini tidak terbukti.

\section{SIMPULAN}

Subjek penelitian yang terdiagnosis MD berdasarkan skor-T DMS sebesar 46,2 \% ( $n=18)$. Semua subjek $(\mathrm{n}=39)$ mengalami defisit energi dan karbohidrat tingkat berat. Hanya 10,2 \% $(\mathrm{n}=4)$ subjek yang asupan proteinnya normal, bahkan terdapat $10,2 \% \quad(\mathrm{n}=4)$ subjek yang termasuk kategori asupan protein berlebih, semuanya mengkonsumsi suplemen penambah massa otot.Hampir seluruh subjek (89,8 \%)mengalami defisit asupan lemak tingkat berat.

Tidak ada hubungan antara muscle dysmorphia dengan asupanenergi, karbohidrat dan protein, namun terdapat hubungan yang signifikan antara muscle dysmorphia dengan asupan lemak, pada pria dewasa usia 19-29 tahun anggota FLOZOR Sport Club Semarang.

\section{SARAN}

Untuk pria dewasa yang melakukan fitness perlu adanya pengawasan dari ahli untuk prngaturan pola makan, sehingga tidak menimbulkan masalah defisiensi gizi, khususnya zat gizi makro. Perlu adanya penelitian lebih lanjut tentang faktor - faktor yang berhubungan dengan muscle dysmorphia yang tidak terjangkau dalam penelitian ini antara lain perilaku makan, pengetahuan tentang gizi seimbang dan ketergantungan latihan. Penelitian serupa pada atlet binaraga professional dapat dilakukan untuk melihat perbedaan muscle dysmorphia dengan asupan energi danzat gizi makro pada atlet binaraga professional dan pelaku latihan angkat beban amatir.

\section{DAFTAR PUSTAKA}

1. Bonnie AS. Nutrition in Adolescence. In: Mahan K, Escott-Stump S, editors. Krause's Food, Nutrition and Diet Therapy.11th edition. Philadelphia: Saunders; 2004.p.288-96

2. Grogan S. Men and Body Image. In: Body Image: Understanding Body Dissatisfaction in Men, Women, and Children. $2^{\text {nd }}$ ed. New York. The Routledge. 2008.p.81.

3. McCreary D.R., Saucier D.M. The Drive for Muscularity and Masculinity: Testing the Associations Among Gender-Role Traits, Behaviors, Attitudes, and Conflict. Psychology of Men and Masculinity.2005;6(2): 83-94

4. Parnell R. The Influence of Self-Esteem and Body Dissatisfaction on Muscle Dysmorphia and Exercise Dependence [Thesis]. Univ. of North Texas.; 2011.

5. Wagner R.R. Body Image Perception of Adolescent Males [Thesis]. Univ. of Wisconsin-Stout.; 2008.

6. Leone J.E., Sedory E.J., Gray K.A.. Recognition and Treatment of Muscle Dysmorphia and Related Body Image Disorder. Journal of Athletic Training. 2005: 40(4):352-359.

7. Olivardia R. The Adonis Complex: The Drive or Muscularity in Boys and Men. Paradigm 2001.p.12.

8. Pope H.G.Jr, Phillips K.A., Olivardia R. The Adonis Complex: The Secret Crisis of Male Body Obsession. New York, NY: The Free Press; 2000

9. Choi P.Y.L., Pope H.G.Jr., Olivardia R. Muscle Dysmorphia: A New Syndrome in Weightlifter. Br J Sports Med 2002;36:375-377. Diunduh dari http://bjsm.bmj.com pada 8 Juli 2012.

10. Shiltz T. Males and Eating Disorders: Research. National Eating Disorders Association. Diunduh dari http://www.NationalEatingDisorders.org

11. Griffiths S., Murray S.B., Touyz S. Disordered Eating and The Muscular Ideal. Journal of Eating Disorders. 2013,1:15. Diunduh dari http://www.jeatdisord.com/content/1/1/15

12. Mosley P.E. Bigorexia: Bodybuilding and Muscle Dysmorphia. Eur. Eat. Disorders Rev. 17.2009;191198 
13. Raevuori A., Keski-Rahkonen A., Bulik C.M., Rose R.J., Rissanen A., Kaprio J. Muscle Dissatisfaction in Young Adult Men.Clinical Practice and Epidemiology in Mental Health 2006, 2:6. Diunduh dari http://biomedcentral.com

14. Contesini N., Adami F., Blake M.T., Monterio C.BM., Sbreu L.C., Valenti V.E., Et.al. Nutritional Strategies of Physically Active Subjects with Muscle Dysmorphia. International Archives of Medicine 2013, 6:25. Diunduh dari http://www.intarchmed.com/content/6/1/25

15. Sastroasmoro S. Dasar - dasar Metodologi Penelitian Klinis. Edisi ke-3. Sagung Seto.2008.hal.188

16. Fridieyanti R., Uripi V., Damanik R. Hubungan Konsumsi Energi-Protein dengan Glukosa Darah dan Tekanan Darah Anak Sekolah Dasar Penerima PMTAS di Kabupaten Kupang Provinsi Nusa Tenggara Timur. In: Media Gizi dan Keluarga,24(2):2000.p.5461

17. McCreary D.R., Sasse D.K. An exploration of the drive for muscularity in adolescent boys and girls. Journal of American College Health, 48, 2000; 297 304.

18. Azwar S. Sikap Manusia Teori dan Pengukurannya. Edisi ke-2. Yogyakarta: Pustaka Pelajar.2009.hal.156

19. WHO. BMI Classification. 2004. Diunduh dari http://apps.who.int/bmi/index.jsp?introPage=intro_3. html\&

20. William M.H. Body Weight and Composition for Health and Sport. In: William M.H. Editor. Nutrition for Health, Fitness, and Sport. $9^{\text {th }}$ edition. NewYork: Graw-Hill.2010

21. Dahlan M.S. Statistik untuk Kedokteran dan Kesehatan. Salemba Medika. 2011. hal.55

22. Henggaryadi G. Hubungan antara Body Image dengan Harga Diri pada Remaja Pria yang Mengikuti Latihan Fitness. [Skripsi]. Universitas Gunadarma. 2008

23. Martin J., Govender A. "Making Muscle Junkies": Investigating Traditional Masculine Ideolody, Body image Discrepancy, and The Pursuit of Muscularity in Adolescent Males. [Serial online]. September 2011. Available from: URL: HYPERLINK http://www.thefreelibrary.com

24. Hildebrandt T., Langenbucher J., Schlundt D.G. Muscularity concern among men: development of attitudinal and perceptual measures.Body Image I.2004:169-181. Diunduh dari www.sciencedirect.com

25. Olivardia R. Muscle Dysmorphia: Characteristic, Assessment, and Treatment. In:Thompson J.K., editor. The Muscular Ideal: Psychological, Social, and Medical Perspectives. Washington,DC. American Psychological Association.2007.p.123-139

26. Chittester N.I., Hausenblas H.A. Correlates of Drive for Muscularity: The Role of Anthropometric Measures and Psychological Factors. Journal of Health Psychology.14(7).2009.p.872-877

27. Sada M. Hubungan Body Image, Pengetahuan Gizi Seimbang, dan Aktivitas Fisik terhadap Status Gizi Mahasiswa Politeknik Kesehatan Jayapura. [Skripsi].
Universitas Hasanddin Makasar. Media Gizi Masyarakat Indonesia.vol.2:1. 2012

28. Riccardelli L.A., McCabe M.P. Pursuit of Muscularity among Adolescents. In: Thompson J.K., editor. The Muscular Ideal: Psychological, Social, and Medical Perspectives. Washington,DC. American Psychological Association.2007.p.199-216

29. Cella S., Iannaccone M., Cotrufo P. Muscle Dysmorphia: A Comparison between Competitive Bodybuilders and Fitness Practitioners. Journal of Nutrition Theurapeutics. 2012.1:12-18

30. WHO. Physical activity and adults. 2010. Diunduh dari

http://www.who.int/dietphysicalactivity/factsheet_ad ults/en/index.html

31. Bahrke M.S. Muscle Enhancement Substance and Strategies. In: Thompson J.K., editor. The Muscular Ideal: Psychological, Social, and Medical Perspectives. Washington,DC. American Psychological Association.2007.p.141-159

32. Field A.E., Austin S.B., Camargo Jr. C.A., Taylor C.B., Striegel-Moore R.H., Loud K.J., Colditz G.A. Exposure to The Mass Media, Body Shape Concerns, and Use of Supplements to Improve Weight and Shape among Male and Female Adolescents. [Serial online]. August 2005. Available from: URL: HYPERLINK pediatrics.aappublications.org/content/116/2/e214

33. Dulloo A.G., Schutz Y. Energy Balance and Body Weight Regulation. In: Catherine G, Hilary P, editors. Human Nutrition. $11^{\text {th }}$ edition. London: Elsevier;2005.p.83-7

34. Kementerian Kesehatan. Peraturan Menteri Kesehatan No.75 Tahun 2013 tentang Angka Kecukupan Gizi yang Dianjurkan bagi Bangsa Indonesia. Departeman Kesehatan. Jakarta.

35. William M.H. Protein: The Tissue Builder. In: William M.H. Editor. Nutrition for Health, Fitness, and Sport. $9^{\text {th }}$ edition. NewYork:Graw-Hill.2010

36. Wolf R. The Paleo Diet Works!. [Online]. Available from: URL: HYPERLINK http://robbwolf.com/whatis-the-paleo-diet/

37. Rodriguez N.R., DiMarco N.M., Lengley S. Nutrition and Athletic Performance. [Serial online]. March 2009. Available from: URL: HYPERLINK http://www.medscape.com

38. Rolfes S.R., Pinna K., Whitney E. The Lipids: Triglycerides, Phospholipids, and Sterols. In: Understanding Normal and Clinical Nutrition. $7^{\text {th }}$ edition. Thomson. 2006.p.140

39. Ettinger S. Macronutrients: Carbohydrates, Proteins, and Lipids. In: Mahan K, Escott-Stump S, editors. Krause's Food, Nutrition and Diet Therapy. $11^{\text {th }}$ edition. Philadelphia:Saunders;2004.p.39

40. Smith A.R., Hawkeswood S.E., Bodell L.P., Joiner T.E. Muscularity versus Leanness: An Examination of Body Ideals and Predictors of Disordered Eating in Heterosexual and Gay College Students. Body Image. 2011.8(3): 232-236 